\title{
Prevalence and antimicrobial susceptibility of Listeria monocytogenes strains isolated from a meat processing plant
}

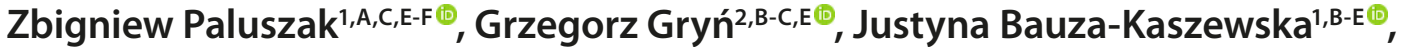 \\ Karolina Jadwiga Skowron ${ }^{3, C, E-F \oplus}$, Natalia Wiktorczyk- Kapischke ${ }^{4, C, E \oplus}$, Jakub Korkus ${ }^{5, C, E \oplus}$,

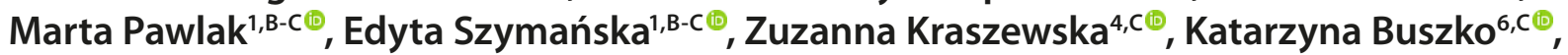 \\ Krzysztof Skowron ${ }^{4, D-F} \odot$
}

\author{
${ }^{1}$ Department of Microbiology and Food Technology, UTP University of Science and Technology, Bydgoszcz, Poland \\ 2 Plant Breeding and Acclimatization Institute - National Research Institute, Bydgoszcz, Poland \\ ${ }^{3}$ Institute of Telecommunications and Computer Science, UTP University of Science and Technology, Bydgoszcz, Poland \\ ${ }^{4}$ Department of Microbiology, Nicolaus Copernicus University in Toruń, Collegium Medicum of L. Rydygier in Bydgoszcz, \\ Poland \\ ${ }^{5}$ Department of Food Hygiene and Consumer Health, University of Environmental and Life Sciences, Wrocław, Poland \\ ${ }^{6}$ Department of Theoretical Foundations of Biomedical Sciences and Medical Computer Science, Nicolaus Copernicus \\ University, Toruń, L. Rydygier Collegium Medium, Bydgoszcz, Poland \\ A - Research concept and design, B - Collection and/or assembly of data, C - Data analysis and interpretation, \\ $D$ - Writing the article, E-Critical revision of the article, F-Final approval of article
}

\begin{abstract}
Paluszak Z, Gryń G, Bauza-Kaszewska J, Skowron KJ, Wiktorczyk- Kapischke N, Korkus J, Pawlak M, Szymańska E, Kraszewska Z, Buszko K, Skowron K. Prevalence and antimicrobial susceptibility of Listeria monocytogenes strains isolated from a meat processing plant. Ann Agric Environ Med. 2021; 28(4): 595-604. doi: 10.26444/aaem/131799
\end{abstract}

\section{Abstract}

Introduction and objective. The ability of $L$. monocytogenes to create biofilm results in the higher resistance to disinfectants and determines the need to search for effective methods of eradication. The aim of the study was to assess the level of L. monocytogenes contamination in the environment of a meat processing plant. The sensitivity of tested isolates to various antimicrobials used for disinfection purposes was also estimated.

Materials and method. The samples were taken from raw materials, semi-finished and final products, as well as food contact surfaces inthe production hall and deli meat packaging department. The number of $L$. monocytogenes and the effect of eight different biocides on bacteria planktonic forms and biofilm formed on stainless steel and polypropylene was investigated. The effect of blood and albumin on L. monocytogenes resistance to disinfectants was also analysed.

Results. The prevalence of $L$. monocytogenes on food contact surfaces was estimated at $2.93 \%$ (10 of 340 swabs taken). The samples of raw and processed products were not contaminated. Various disinfectants reduced the growth of planktonic L. monocytogenes forms at both tested concentrations $0.5 \%$ and $0.1 \%$ (irrespective of time exposure). The highest efficacy against $L$. monocytogenes biofilm was reported for agents containing hydrogen peroxide. The reduction of bacteria number ranged from 6.93-7.21 log CFU $\times \mathrm{cm}-2$, and was dependent on the surface type and time of agent application.

Conclusions. In this study, the effectiveness of various disinfectants against planktonic bacteria and Listeria biofilm was observed. For the majority of disinfectants, the extension of time exposure increased bacteria elimination from the biofilm. The presence of blood resulted in reduction of the antilisterial action of most of the disinfectants applied at low concentrations.

- Key words

biofilm, disinfection, Listeria monocytogenes, meat processing plant, antimicrobial susceptibility

\section{INTRODUCTION}

Listeria monocytogenes, a causative agent of listeriosis, is a Gram-positive, non spore-forming bacterium, widely spread in different environments. Frequently isolated from soil, water, sewage and faeces, L. monocytogenes may also colonize human and animal organisms. The microorganism is highly resistant to a variety of stress factors, including high osmotic pressure or unfavourable $\mathrm{pH}$ values. The ability to grow at low temperatures $\left(2-4^{\circ} \mathrm{C}\right)$ makes L. monocytogenes

Address for correspondence: Krzysztof Skowron, Department of Microbiology, Nicolaus Copernicus University, Toruń, Collegium Medicum of L. Rydygier, Bydgoszcz, M. Skłodowskiej-Curie 9, 85-094, Bydgoszcz, Poland

E-mail: skowron238@wp.pl

Received: 06.08.2020; accepted: 17.12.2020; first published:04.01.2021 a pathogen of particular concern in many branches of the food industry $[1,2]$.

The main source of human listeriosis is food, and the products most frequently implicated are milk and dairy products, especially soft cheeses, meat and its products, fish, RTE food (ready-to-eat), raw vegetables, fruit and vegetable salads [3]. According to an EFSA report, the food vehicle linked to the most strong-evidence for food-borne outbreaks in 2018 were vegetables, juices and other similar products [4]. In the case of meat RTE (ready to eat) products, L. monocytogenes was found in $1.4 \%$ (559/41,417 samples) at all stages of sampling [4].

According to the EFSA, although relatively rarely reported, listeriosis is one of the most serious food-borne diseases with the highest mortality rate $(15.6 \%)$ and proportion 
of hospitalised cases from all zoonoses in the European Union [4].

Widespread listeriosis outbreaks observed over the last 5 years confirm the increasing threat related to Listeria infections. Over 200 deaths have been reported during the largest L. monocytogenes outbreak in 2017-2018 in South Africa. Ready-to-eat processed meat products were the source of pathogenic bacilli [5]. During a 2015-2018 multi-country outbreak of L. monocytogenes (47 cases, 9 deaths), the source of bacteria was frozen corn [6]. Recent outbreaks include from October 2019 (Germany - 2 deaths; source - deli meat) and from September 2019 (USA - 10 confirmed cases, 1 death; source - deli meat and cheese) [7].

The contamination of food may occur during all stages of its processing, distribution, sale and preparation by the individual consumers. An important source of L. monocytogenes is the equipment used during food processing, as well as all food contact surfaces [8]. L. monocytogenes is able to adhere to such surfaces and form biofilm. Biofilm protects the bacteria against physical (dessication) and chemical (disinfectants, antibiotics) agents, but also affect cell-to-cell communication (quorum sensing) and is self-organization within the biofilm [9]. Lately, many alternative methods of L. monocytogenes inactivation in the food have been investigated, including the use of essential oils, active packaging, and bio-protection [10]. Nonetheless, chemical disinfection seems to be the most effective and economically reasonable way for pathogen elimination in the food processing environment. The most commonly used chemical disinfectants include: chlorine based compounds, iodophores, peroxide compounds, alcohols, aldehydes, surfactants (QAC), nitrogen compounds, organic and inorganic acids, and heavy metal compounds. The composition of the chemical agent, the concentration of working solution and the time of action are crucial for efficient disinfection [11].

The use of chemical disinfectants in the food processing environment is usually based on their effectiveness, confirmed in tests performed on bacteria planktonic form [12]. However, in an industrial environment, bacteria develop a biofilm forming a protective extracellular matrix composed of polysaccharides, proteins and/or extracellular DNA [13]. The presence of by-products during food production (meat juice, pork serum or fat) has been shown to stimulate biofilm development $[14,15]$. Possible mechanisms effecting the low effectiveness of conventional biocides on biofilms include inhibition of the diffusion - reaction, associated with the biofilm matrix, slow growth and development of remaining cells subpopulations [10]. In turn, the low effectiveness of disinfectants against biofilms depends, at least partially, on the characteristics of the surface on which the biofilm was formed [16]. It has been shown that cracks or scratches on the surfaces used in the food industry promote the development of biofilms and decrease the effectiveness of antimicrobial conventional disinfectants [17]. Therefore, it is necessary to investigate various types of surfaces when evaluating the effectiveness of biocides against the biofilm of L. monocytogenes.

\section{OBJECTIVE}

The aim of the study was to assess the incidence of L. monocytogenes ina meat processing plant (surfaces, equipment, food products). The effectiveness of selected disinfectants on planktonic cells and biofilm of bacteria on the polypropylene and stainless steel was also investigated.

\section{MATERIALS AND METHOD}

The research material consisted of 340 swabs taken from raw materials, semi-finished and final products (33 swabs), as well as working surfaces and equipment in the production hall (134 swabs) and deli meat packaging department (173 swabs) in a meat processing plant in Northern Poland (sampling in accordance with the PN-ISO 18593 norm) [18]. The swabs were collected immediately after disinfection procedures, as well as during the production process; all the swabs taken at at the same time in a particular sampling term. Sampling procedures took from 3-4 hours, depending on the numbers of swabs collected. The samples were always taken from the sampling area of $100 \mathrm{~cm}^{2}$, in three repetitions, from May December 2018. The swabs were transported to the meat processing plants in sterile plastic tubes containing sterile liquid medium. The time between sampling procedures and laboratory analysis ranged from $2-4$ hours.

Detection of L. monocytogenes. Isolation of L. monocytogenes from the swabs was performed in accordance with the PN-EN ISO 11290-1:2017:07 norm [19]. The samples were incubated in $4.5 \mathrm{ml}$ half-Fraser broth $\left(24 \mathrm{~h}, 37^{\circ} \mathrm{C}\right)$. Next, $0.1 \mathrm{ml}$ of the suspension was transferred to the Fraser broth $(9.9 \mathrm{ml})$, then, after $48 \mathrm{~h}$ incubation at $37^{\circ} \mathrm{C}$ on the agar medium for Listeria, according to Ottaviani and Agosti (ALOA, MERCK). The incubation was carried out for $24-48$ hours at $37^{\circ} \mathrm{C}$. Greenblue colonies surrounded by an opaque zone were used for further analysis. All characteristic colonies per plate were used for further analysis.

DNA isolation. Total genomic DNA was isolated from the samples using a Genomic Mini AXE Bacteria Spin column kit (A\&A Biotechnology, Poland), according to the manufacturer procedure. The concentration and purity of the DNA was verified using biophotometer (Eppendorf BioPhotometer D30).

Species identification using multiplex-PCR. Two genes were used for L. monocytogenes species identification (Tab. 1) [20, 21]. The PCR mix of $25 \mu \mathrm{L}$ volume contained $1 \times \mathrm{PCR}$ buffer (Promega); $25 \mathrm{mM} \mathrm{MgCl}_{2}$ (Promega); $10 \mathrm{mM} \mathrm{dNTP} \mathrm{Solution}$ Mix (Promega); $10 \mu \mathrm{M}$ of each primer pair (Oligo.pl); $1 \mathrm{U}$ Taq DNA polymerase (Promega); $2 \mu \mathrm{L}$ of template DNA ( $25 \mathrm{ng} / \mu \mathrm{l}$; $\mathrm{A}_{260} / \mathrm{A}_{280}=1.92 \pm 0.18$ ), and sterile, double-distilled water. The amplification protocol included: initial DNA denaturation for $2 \mathrm{~min}$ at $94^{\circ} \mathrm{C} ; 30$ cycles of $30 \mathrm{~s}$ denaturation at $94^{\circ} \mathrm{C}$, annealing for $30 \mathrm{~s}$ at $50^{\circ} \mathrm{C}$ and elongation for $1 \mathrm{~min}$ at $72^{\circ} \mathrm{C}$, followed by the final elongation step of $5 \mathrm{~min}$ at $72^{\circ} \mathrm{C}$. The

Table 1. Primer sequence (Leclercq et al., 2010; Skowron et al., 2018b)

\begin{tabular}{|c|c|c|c|c|}
\hline Primer & Primer sequence $(5 \rrbracket \square 3 \rrbracket)$ & $\begin{array}{l}\text { Target } \\
\text { gene }\end{array}$ & $\begin{array}{l}\text { Information } \\
\text { about gene }\end{array}$ & $\begin{array}{c}\text { Amplicon } \\
\text { size [bp] }\end{array}$ \\
\hline L1 & CAG CAG CCG CGG TAA TAC & \multirow{2}{*}{$r r s$} & \multirow{2}{*}{$\begin{array}{l}\text { Typical for } \\
\text { Listeria spp. }\end{array}$} & \multirow{2}{*}{938} \\
\hline L2 & CTC CAT AAA GGT GAC CCT & & & \\
\hline LM1 & CCT AAG ACG CCA ATC GAA & \multirow{2}{*}{ hlyA } & \multirow{2}{*}{$\begin{array}{l}\text { Typical for Listeria } \\
\text { monocytogenes }\end{array}$} & \multirow{2}{*}{700} \\
\hline LM2 & AAG CAC TTG CAA CTG CTC & & & \\
\hline
\end{tabular}


PCR reaction was carried out using a thermocycler Eppendorf (Mastercycler X50). The amplified DNA fragments were separated on $1.5 \%(\mathrm{w} / \mathrm{v})$ agarose gel, in a TBE buffer, and detected by staining with Midori Green (NIPPON Genetics EUROPE GmbH).

Molecular weights of the fragments were estimated using a 100-1,000 bp DNA molecular marker (A\&A Biotechnology, Poland). Listeria monocytogenes ATTC 7644 was used as the reference strain.

Genetic similarity evaluation (RAPD-PCR). The genetic relatedness of isolates was performed using RAPDPCR (Random Amplification of Polymorphic DNA) [22]. The reaction included a single primer OPA-11 (5'CAATCGCCGT-3区) [23]. The reaction of $25 \mu \mathrm{L}$ volume contained $1 \times$ PCR buffer with $2 \mathrm{mM} \mathrm{MgCl}_{2}$ (Promega); 200 $\mu \mathrm{M}$ dNTP Solution Mix (Promega); $1 \mu \mathrm{M}$ single OPA-11 primer (Oligo.pl); $1.25 \mathrm{U}$ Taq DNA polymerase (Promega); 3 $\mu \mathrm{L}$ of template DNA $\left(25 \mathrm{ng} / \mu \mathrm{l} ; \mathrm{A}_{260} / \mathrm{A}_{280}=1.92 \pm 0.18\right)$ and water.

The amplification protocol included: 6 cycles of initial DNA denaturation for $1 \mathrm{~min}$ at $94^{\circ} \mathrm{C}$; annealing for $2 \mathrm{~min}$ at $30^{\circ} \mathrm{C}$, and elongation for $1 \mathrm{~min}$ at $72^{\circ} \mathrm{C}$, next 35 cycles of denaturation for $15 \mathrm{~s}$ at $94^{\circ} \mathrm{C}$; annealing for $40 \mathrm{~s}$ at $37^{\circ} \mathrm{C}$, elongation for $35 \mathrm{~s}$ at $72^{\circ} \mathrm{C}$, followed by a final extension step of $10 \mathrm{~min}$ at $72^{\circ} \mathrm{C}$. The PCR reaction was carried out using a thermocycler Eppendorf (Mastercycler ${ }^{\oplus}$ X50).

The amplified DNA fragments were separated on $2.0 \%$ $(w / v)$ agarose gel by eletrophoresis, in a TBE buffer, and detected by staining with Midori Green. To evaluate the genetic similarity, a phylogenetic dendrogram was plotted in the CLIQS 1D Pro software (TotalLab). Clustering analysis was performed using the UPGMA hierarchical grouping technique (Unweighted Pair Group Method of Arithmetic Means). Measures of genetic uniformity among recovered individuals were determined using the dice dissimilarity coefficient.

Effect of disinfectants on planktonic bacilli of L. monocytogenes. The effect of 8 disinfectants, containing following active substances, on $6 \mathrm{~L}$. monocytogenes isolates of genetically different profiles and the reference strain ATTC 7644 was investigated:

D1 - sodium hydroxide $(5-<10 \%)$, sodium hypochlorite $(<10 \%, 5 \mathrm{~g} / 100 \mathrm{~g})$.

D2 - phosphoric acid (V) (20-<50\%), amine (1-<5\%), hydrochloric acid (1-<5\%), didecyldimethylammonium chloride (5\%), propan-2-ol $(1-<5 \%)$.

D3 - hydrogen peroxide (20 $-<50 \%)$, acetic acid $(10-<20 \%)$, peracetic acid $(10-<20 \%)$.

D4 - nitric acid (V) (20-<50\%), phosphoric acid (V) (5$<10 \%)$.

D5 - sodium hypochlorite ( $<10 \% ; 5.2 \mathrm{~g} / 100 \mathrm{~g})$, sodium hydroxide $(-<10 \%)$, amines C12-14-alkyldimethyl $(4.5 \mathrm{~g} / 100 \mathrm{~g})$, n-oxides $(1-<5 \%)$.

D6 - didecyldimethylammonium chloride (5g/100g), quaternary ammonium compounds benzyl C12-16 alkyldimethyl, chlorides $(4.5 \mathrm{~g} / 100 \mathrm{~g})$, propan-2-ol (5$<10 \%)$.

D7 - propan-1-ol (45g/100g), propan-2-ol (30g/100g)

D8 - propan-1-ol (50\%), propan-2-ol (30\%).

Three concentrations of disinfectants were applied: 0.01 , 0.1 and $0.5 \%$ (final concentration).
A sample of $20 \mu \mathrm{l}$ of bacterial suspension ( $0.5 \mathrm{McF}$ arland scale $\left.-7.80 \times 10^{7}\left( \pm 1.66 \times 10^{7}\right) \mathrm{CFU} \times \mathrm{cm}^{-3}\right)$ in a sterile brainheart broth (BHI, Beton-Dickinson) was placed in the microtiter plate and $160 \mu \mathrm{l}$ of the disinfectant was added. The effect of the addition of 2 loading substances - bovine albumin $(0.3 \%$ solution in demineralized water) and dried blood $(0.3 \%$ solution in demineralized water) was also assessed. For that, $20 \mu \mathrm{l}$ of bacterial suspension and $20 \mu \mathrm{l}$ loading substance were mixed with $160 \mu$ l of disinfectant at the concentration given above. The disinfectant action was determined after 1 and $5 \mathrm{~min}$. Then, $20 \mu \mathrm{l}$ of the tested sample was transferred into $180 \mu \mathrm{l}$ of neutralizing solution, i.e. nutrient broth $(1,000 \mathrm{ml})$, lecithin $\left(3.0 \mathrm{~g} \mathrm{l}^{-1}\right)$, histidine 1 $\left(1.0 \mathrm{~g} \mathrm{l}^{-1}\right)$, anhydrous sodium thiosulphate $\left(7.84 \mathrm{~g} \mathrm{l}^{-1}\right)$ and Tween $80\left(30.0 \mathrm{~g} \mathrm{l}^{-1}\right)$ [24], and was incubated for $2 \mathrm{~min}$ at room temperature. Next, $20 \mu \mathrm{l}$ of the neutralised solution of each sample was placed onto Tryptic Soya Agar (TSA, Merck) and was incubated for $24 \mathrm{~h}$ incubation at $37^{\circ} \mathrm{C}$.

Biofilm formation by L. monocytogenes strains on 2 surfaces, and the effect of disinfectants on cells in the biofilm. The surfaces tested included elements made of stainless steel and polypropylene (size: $10 \mathrm{~mm} \times 20 \mathrm{~mm}$ ). The fragments were cut using hydroabrasive technology, and sterilized by washing with $70 \%$ ethanol, rinsing with deionized water, drying and irradiation with high energy electron beam ( $25 \mathrm{kGy}$ ) (limiting the effect of high temperature on surface properties). Suspensions of the previously tested L. monocytogenes strains and the reference L. monocytogenes strain ATTC 7644 (0.5 McFarland scale) in a sterile brainheart broth (BHI, Beton-Dickinson) were prepared. The tested surfaces were immersed in such a bacterial suspension and transferred to a fresh sterile BHI broth every $24 \mathrm{~h}\left(37^{\circ} \mathrm{C}\right)$. After $72 \mathrm{~h}$, the surfaces were rinsed twice with buffered saline (0.9\% PBS; Avantor).

The surfaces covered with a biofilm, were placed in disinfectant solutions prepared according to the PN-EN-1276 norm [25].

Disinfectants were applied for $1 \mathrm{~min}$ and $5 \mathrm{~min}$ in the concentration of $0.5 \%$ for D1 - D6 disinfectants (except D3 disinfectant, applied on the biofilm formed on stainless steel in concentration of $0.3 \%$ ). Undiluted disinfectants D7 and D8 were used in the experiment. Exposure times to disinfectants were established based on previously conducted pre-experimental trials.

The steel and polypropylene fragments were then immersed in a neutralizing solution ( $2 \mathrm{~min})$, transferred into PBS and sonicated for $10 \mathrm{~min}(30 \mathrm{kHz}, 150 \mathrm{~W})$. A series $10-$ fold dilutions of the suspension in physiological saline were plated onto Tryptic Soya Agar (TSA, Merck). After 24-48 h incubation at $37^{\circ} \mathrm{C}$, the recovered colonies were counted and expressed as the logarithm of the number of colony-forming units (CFU) per $1 \mathrm{~cm}^{2}$ of the surface tested. Logarithmic declines in the number of $L$. monocytogenes after disinfectant application, relative to the control, were calculated. Each experiment was repeated 3 times for all tested strains. As a control, hard water was used instead of disinfectant.

Statistical analysis. Mixed models with random effects where applied in order to analyze the declines in bacteria number, dependent on time, surface and disinfectant type. The Maximum likelihood method was applied for estimating the variance. All analyses were performed in R software. 
Further statistical analysis was performed using Statistica 12.0 PL tools (StatSoft). The normality of data distribution for the calculated logarithmic declines in the number of L. monocytogenes bacilli and the means for all strains tested was checked using the Shapiro-Wilk test. A two-way analysis of variance (ANOVA with Tukey post hoc test ( $\mathrm{p} \leq 0.05$ ) were used to determine whether the significant differences existed between the experimental groups. The surface and disinfectant types were considered as the independent variables, while the logarithmic decline of bacteria number as a dependent variable.

\section{RESULTS}

Species identification. Twenty of the strains isolated from the analyzed samples were confirmed to be Listeria spp. (14 from the production hall and 6 from the deli meat packaging department). The presence of $h l y A$ and $r r s$ genes was detected in 10 isolates ( 6 from the production hall and 4 from the deli meat packaging department), which were classified as L. monocytogenes (2.93\% of all samples tested) (Tab. 2). None of the raw material, semi-final and final meat product samples, contained Listeria spp.

Table 2. Characteristic of L. monocytogenes isolates

\begin{tabular}{lcc}
\hline L. monocytogenes strain & Isolation date & Sample origin \\
\hline $\operatorname{Lm} 1$ & 15.05 .18 & meat saw grill \\
\hline $\mathrm{Lm} 2$ & 04.06 .18 & smokehouse flooring \\
\hline $\mathrm{Lm} 3$ & 04.06 .18 & smokehouse sewage grate \\
\hline $\mathrm{Lm} 4$ & 13.06 .18 & meat trolley \\
\hline $\mathrm{Lm} 5$ & 25.06 .18 & corridor sewage grate \\
\hline $\mathrm{Lm} 6$ & 06.08 .18 & smokehouse flooring \\
\hline $\mathrm{Lm} 7$ & 06.08 .18 & brinemixer \\
\hline $\mathrm{Lm} 8$ & 06.08 .18 & flooring in containers wash \\
\hline $\mathrm{Lm} 9$ & 22.10 .18 & meat mincer \\
\hline $\mathrm{Lm} 10$ & 19.11 .18 & flooring in pallet (palox) wash \\
\hline
\end{tabular}

Genetic relatedness of $L$. monocytogenes strains. The analysis of genetic similarity of $L$. monocytogenes isolates revealed the presence of 2 major phylogenetic groups. Six genetically different profiles were found. Strains Lm9/ Lm6/ $\mathrm{Lm} 3, / \mathrm{Lm} 2$ and $\mathrm{Lm} 8 / \mathrm{Lm} 7$ represented single genotypes (Fig. 1).
Table 3. Results of using mixed models with random effects

\begin{tabular}{lccccc}
\hline Value & Value & Std.Error & DF & t-value & p-value \\
\hline Intercept) & 2.35584 & 0.35089 & 183 & 6.71399 & 0 \\
\hline Factor (Time) 2 & 1.88142 & 0.27251 & 183 & 6.90399 & 0 \\
\hline Factor (Surface) S & 0.75142 & 0.27251 & 183 & 2.757395 & 0.00642 \\
\hline Disinfectant & 0.2222 & 0.05811 & 183 & 3.82377 & 0.00018 \\
\hline & & & & & \\
\hline Value & Value & Std.Error & DF & t-value & p-value \\
\hline Intercept) & 2.63227 & 0.31944 & 176 & 8.24028 & 0 \\
\hline Factor (Time) 2 & 1.98023 & 0.20472 & 176 & 9.67289 & 0 \\
\hline Factor (Surface) S & 0.85023 & 0.20472 & 176 & 4.15314 & $5,00 \mathrm{E}-05$ \\
\hline Factor (Disinfectant) 2 & -0.60083 & 0.40044 & 176 & -1.50044 & 0.13529 \\
\hline Factor (Disinfectant) 3 & 2.89000 & 0.40044 & 176 & 7.21708 & 0 \\
\hline Facto (Disinfectant) 4 & -0.77125 & 0.40044 & 176 & -1.92601 & 0.05571 \\
\hline Factor (Disinfectant) 5 & -0.33292 & 0.40044 & 176 & -0.83138 & 0.40689 \\
\hline Factor (Disinfectant) 6 & -0.34917 & 0.40044 & 176 & -0.87196 & 0.38442 \\
\hline Factor (Disinfectant) 7 & 2.01083 & 0.40044 & 176 & 5.02157 & 0 \\
\hline Factor (Disinfectant) 8 & 2.54591 & 0.43532 & 176 & 5.84832 & 0 \\
\hline Factor (Disinfectant) 9 & 1.18727 & 0.65019 & 176 & 1.82605 & 0.06954 \\
\hline
\end{tabular}

Results of statistical analysis. The results of using mixed models with random effects where applied in order to analyze the declines in bacteria number dependent on time, surface and disinfectant type is presented in Table 3.

Time 2 has an impact on declines in bacteria number in relation to Time 1 . Shifting from Time 1 to Time 2 increases the decline by 1.88 if the surface and disinfectant are constant.

Surface $S$ has an impact on declines in bacteria number in relation to Surface P. Shifting from a Surface P to Surface $S$ increases the declines by 0.75 if time and disinfectant are constant.

Disinfectant has an impact on declines in bacteria number. Changing the disinfectant increases the declines by 0.22 if the surface and time are constant.

Effect of disinfectants on planktonic bacilli of L. monocytogenes. The most effective anti-isterial agents were D1 (sodium hydroxide, sodium hypochlorite), D2 (phosphoric acid (V), amine, hydrochloric acid, didecyldimethylammonium chloride, propan-2-ol), D5 (sodium hypochlorite, sodium hydroxide, amines C12-14-alkyldimethyl, n-oxides) and D6 (didecyldimethylammonium chloride, quaternary ammonium compounds, and propan-2-ol). The majority of these

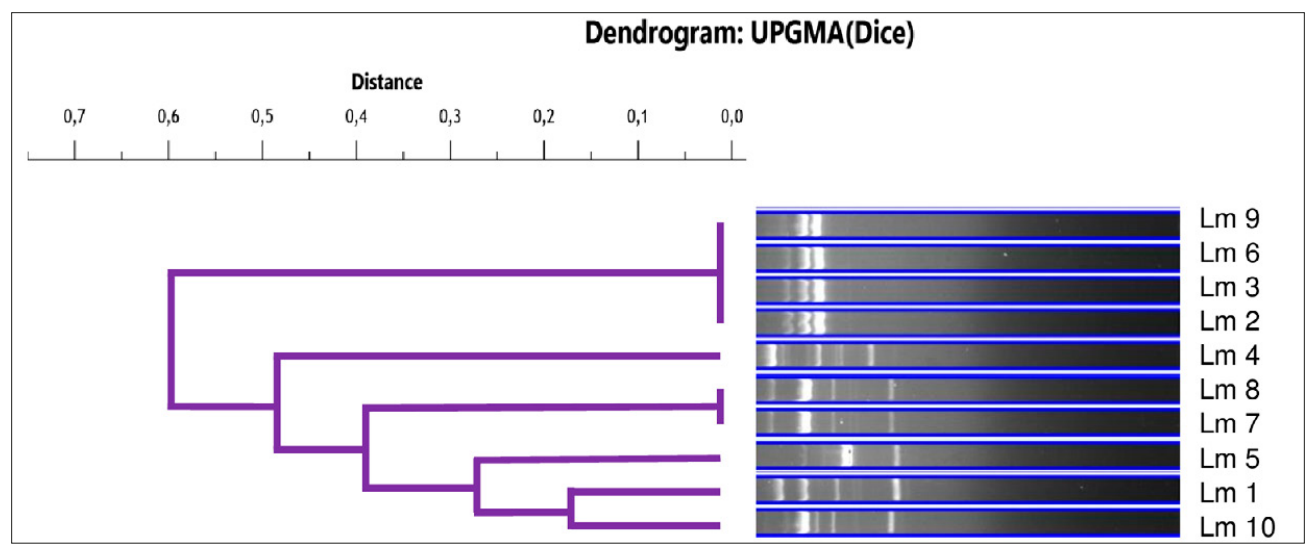

Figure 1. Genetic similarity dendrogram of the Listeria monocytogenes isolates 
Table 4. Effect of disinfectants and loading substances on L. monocytogenes planktonic cells

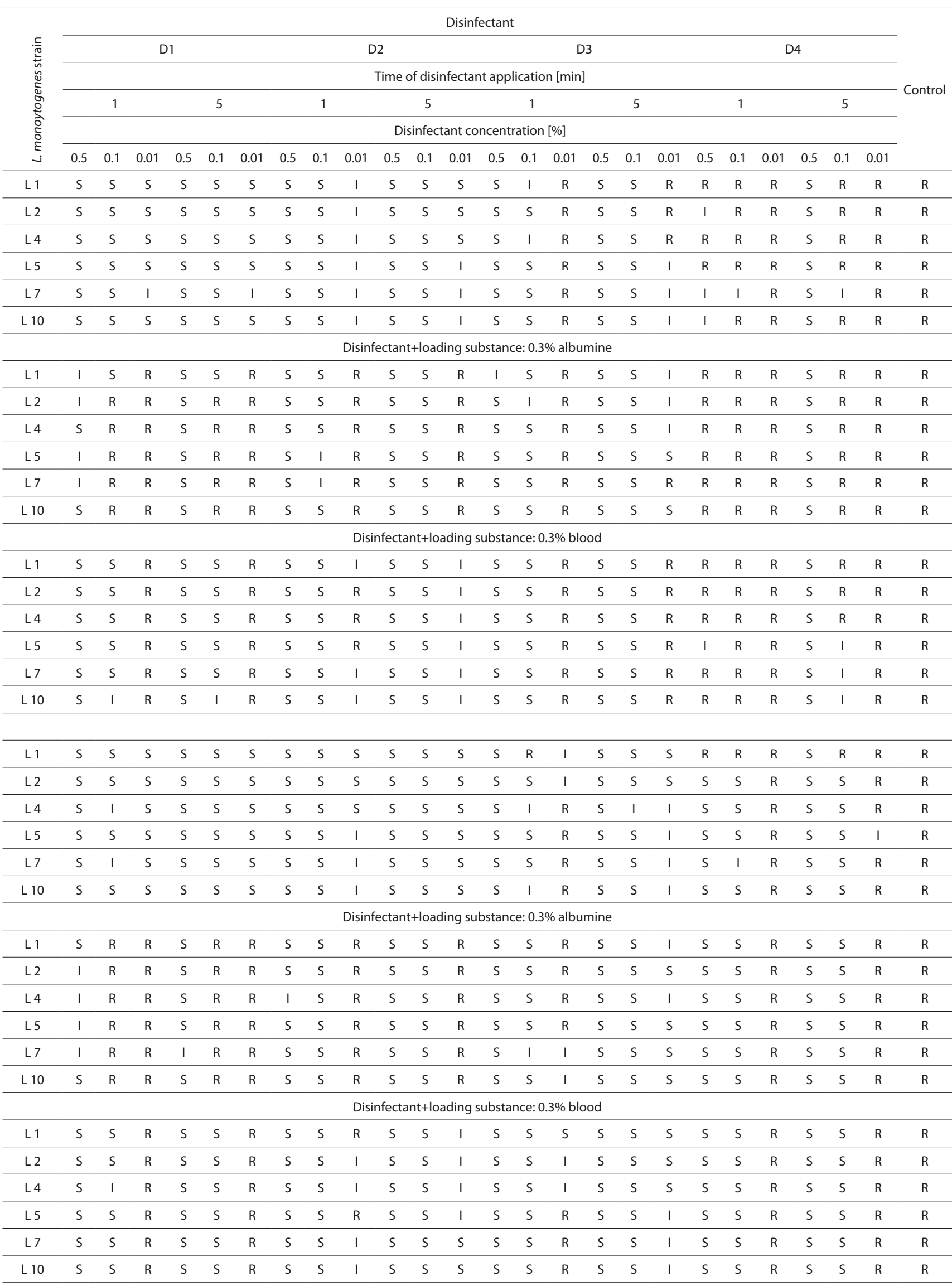


disinfectants inhibited almost all L. monocytogenes strains tested at concentrations of $0.5 \%$ and $0.1 \%$, irrespective of the time exposure. The addition of albumin and blood decreased the effectiveness of D1 and D5 agents at concentrations 0.1 and $0.01 \%$. In the case of D2 and D6 disinfectants, albumin addition resulted in lower anti-listerial efficiency at $0.01 \%$ concentration (Tab. 4).

The lowest susceptibility of $L$. monocytogenes strains was recorded for D4 disinfectant (nitric acid (V), phosphoric acid $(\mathrm{V})$, which reduced bacilli only at the highest concentration of $0.5 \%$. The addition of albumin and blood did not affect its efficacy (Tab. 4).

Effect of disinfectants on L. monocytogenes cells in biofilm. All the disinfectants applied in the study reduced the number of $L$. monocytogenes cells in the biofilm formed on the tested surfaces. Both the surface type and time of disinfectant exposure affected the level of bacterial reduction (Fig. 2).

Regardless of the disinfectant composition, after 1 minute exposure, a higher anti-listerial activity was observed on the steel surface. However, for almost all of disinfectants tested (except D6), no significant differences were noticed between the steel and polypropylene. The best efficacy was observed for D3 (containing hydrogen peroxide, acetic acid, peracetic acid), D7 and D8 (containing propan-1-ol, propan2 -ol). The decrease in bacilli number ranged from 5.99$6.93 \log \mathrm{CFU} \times \mathrm{cm}^{-2}$ and from 5.21-6.7 $\mathrm{CFU} \times \mathrm{cm}^{-2}$ for the steel and polypropylene, respectively, and was significantly higher compared to all other compounds. In turn, the lowest reduction in the L. monocytogenes number after 1-min exposure was reported for D4 disinfectants (containing nitric (V) and phosphoric acids) and hardly exceeded 1 log $\mathrm{CFU} \times \mathrm{cm}^{-2}$ (Fig. 2).

The extension of disinfectant exposure increased the reduction of bacterial cells in the biofilm. Five of 8 agents tested demonstrated higher effectiveness against L. monocytogenes on steel surface, but significant differences were noted only for 1 disinfectant - D6 (didecyldimethylammonium chloride, QAC). The greatest efficiency of the tested compounds after 5 min contact on both surfaces was observed for D3, D7 and D8 disinfectants. The highest logarithmic decrease in the number of bacilli (7.21 log $\mathrm{CFU} \times \mathrm{cm}^{-2}$ ) was recorded in the case of D3 disinfectant on a polypropylene surface (Fig. 3).

\section{DISCUSSION}

L. monocytogenes is a pathogen posing a threat to consumers due to its presence in food processing plants, and the high mortality rate for listeriosis. Among the main sources of L. monocytogenes are meat and sausages. Five deaths related to L. monocytogenes isolated from pig meat were reported in Germany and the Netherlands in October 2019 [26]. The presence of $L$. monocytogenes in meat processing plants has been noted by many researchers $[27,28]$. The main source of the bacteria was the raw materials delivered to the plant. Since insufficient cleaning and disinfection procedures did not eliminate $L$. monocytogenes, transmission within the production hall occurred, resulting in the increased risk of secondary contamination of the final products [28]. Cleaning and disinfection procedures, especially in hard-to-reach places, are often insufficient to eliminate microorganisms from the food processing environment. In the current study, 20 strains of Listeria spp. were isolated, 14 from the production hall and 6 from the deli meat packaging department. L. monocytogenes strains, whose presence was confirmed in $2.93 \%$ of all samples tested, were also isolated only from production areas -6 from the production hall and 4 from the deli meat packaging department. No Listeria spp.

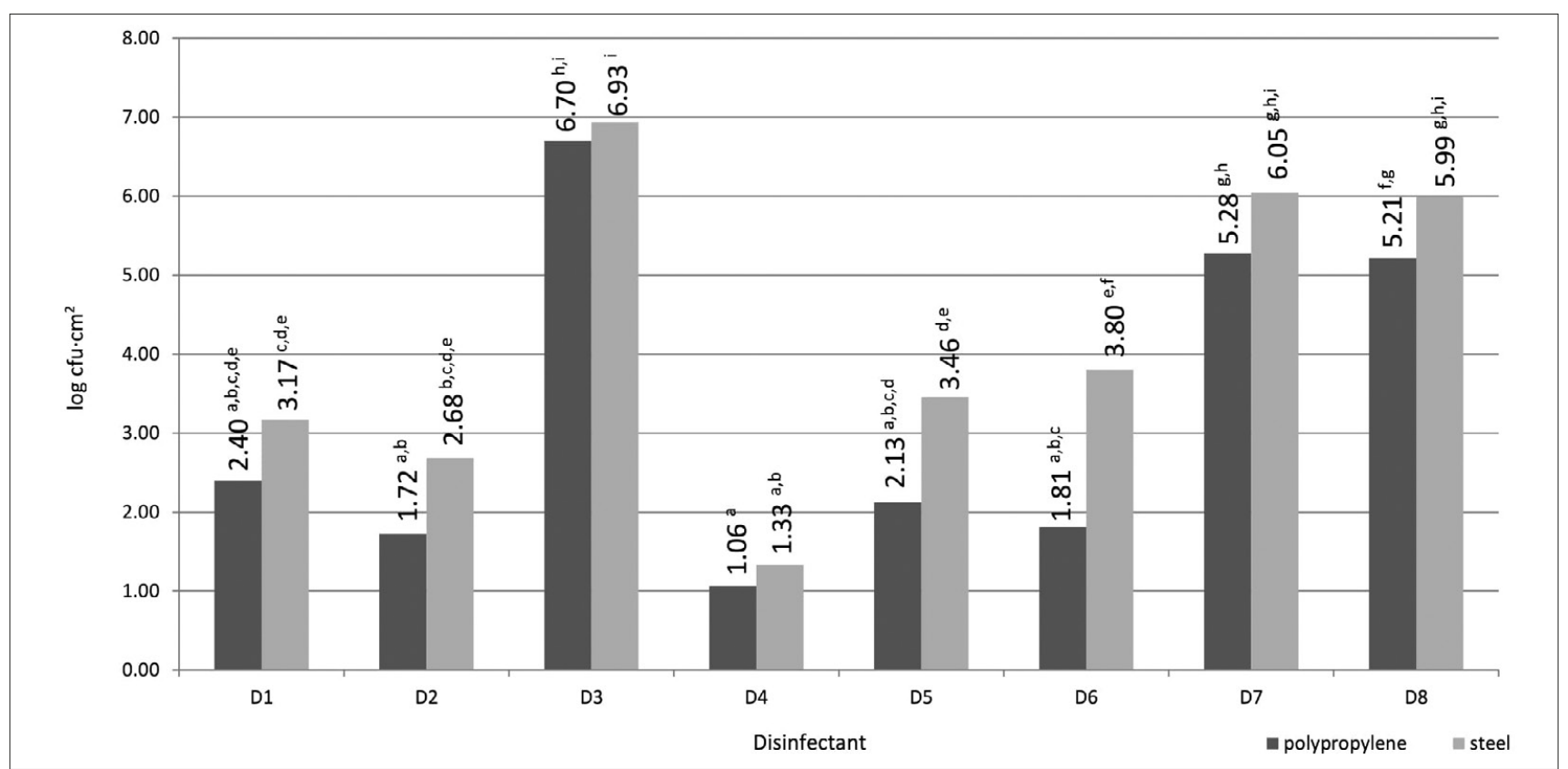

Figure 2. Logarithmic reduction of $L$. monocytogenes count (average values for all tested strains) after 1-minute exposure of various disinfectants in the biofilm formed on the steel and polypropylene surfaces $(a, b, c, \ldots$ - values marked with different letters differ statistically significantly), D1- sodium hydroxide (5 -<10\%), sodium hypochlorite $(<10 \%, 5 \mathrm{~g} / 100 \mathrm{~g})$; D2 - phosphoric acid $(\mathrm{V})(20-<50 \%)$, amine $(1-<5 \%)$, hydrochloric acid $(1-<5 \%)$, didecyldimethylammonium chloride $(5 \%)$, propan-2-ol $(1-<5 \%)$; D3 - hydrogen peroxide ( $20-<50 \%)$, acetic acid (10-<20\%), peracetic acid (10-<20\%); D4 - nitric acid (V) $(20-<50 \%)$, phosphoric acid (V) $(5-<10 \%)$; D5 - sodium hypochlorite $(<10 \% ; 5.2 \mathrm{~g} / 100 \mathrm{~g})$, sodium hydroxide $(-<10 \%)$, amines $C 12-14$-alkyldimethyl $(4.5 \mathrm{~g} / 100 \mathrm{~g})$, $\mathrm{n}$-oxides (1-<5\%); D6 - didecyldimethylammonium chloride $(5 \mathrm{~g} / 100 \mathrm{~g})$, quaternary ammonium compounds benzyl C12-16 alkyldimethyl, chlorides (4.5g/100g), propan-2-ol (5-<10\%); D7 - propan-1-ol (45g/100g), propan-2-ol (30g/100g); D8 - propan-1-ol (50\%), propan-2-ol (30\%) 


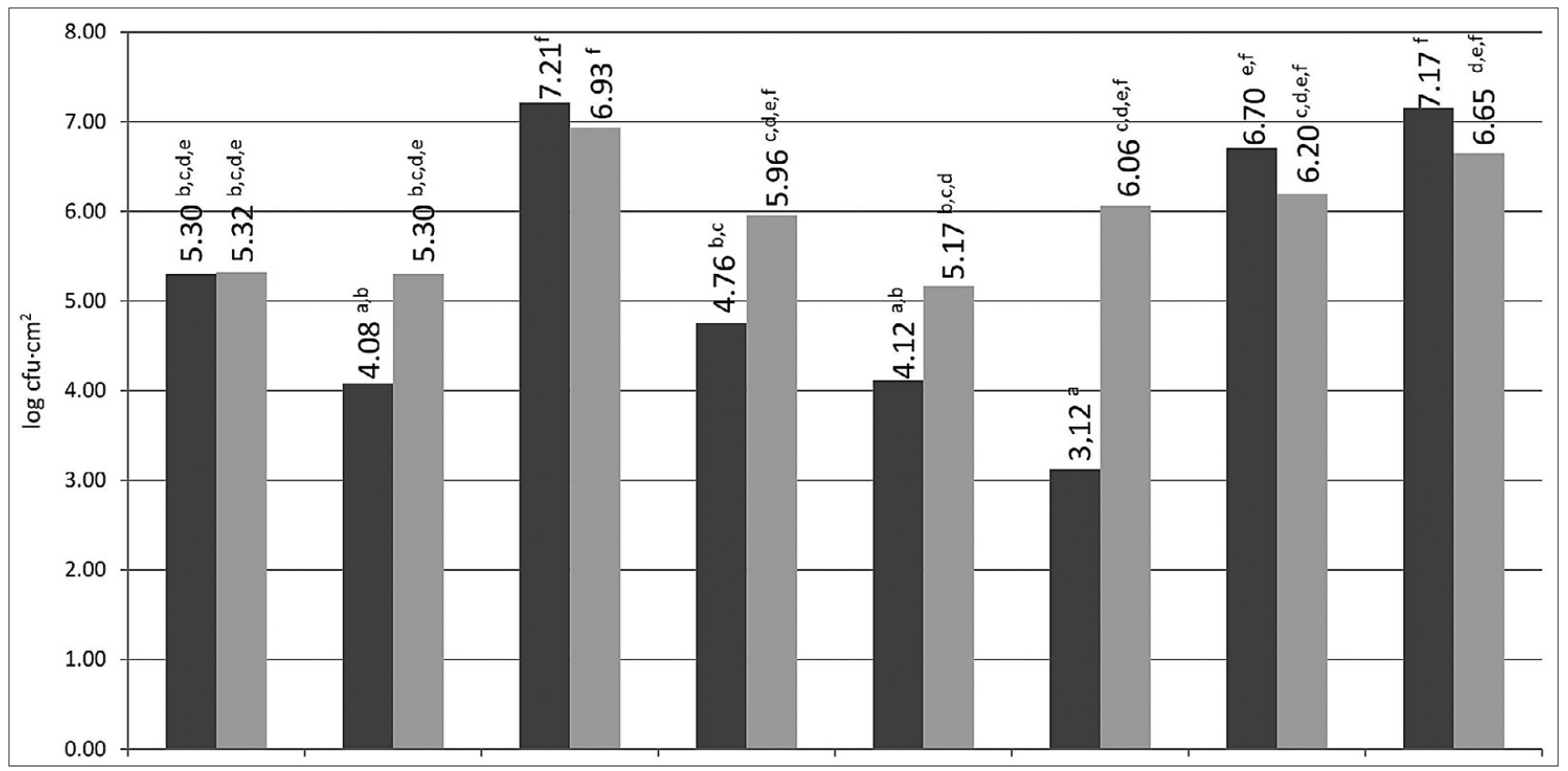

Figure 3. Logarithmic reduction of L. monocytogenes count (average values for all tested strains) after 5 -minute exposure of various disinfectants in the biofilm formed on the steel and polypropylene surfaces ( $a, b, c, \ldots-$ values marked with different letters differ statistically significantly), D1- sodium hydroxide (5 -<10\%), sodium hypochlorite $(<10 \%, 5 \mathrm{~g} / 100 \mathrm{~g})$; D2 - phosphoric acid (V) $(20-<50 \%)$, amine $(1-<5 \%)$, hydrochloric acid $(1-<5 \%)$, didecyldimethylammonium chloride $(5 \%)$, propan-2-ol $(1-<5 \%)$; D3 - hydrogen peroxide ( $20-<50 \%)$, acetic acid (10-<20\%), peracetic acid (10-<20\%); D4 - nitric acid (V) $(20-<50 \%)$, phosphoric acid (V) $(5-<10 \%)$; D5 - sodium hypochlorite $(<10 \% ; 5.2 \mathrm{~g} / 100 \mathrm{~g})$, sodium hydroxide $(-<10 \%)$, amines $\mathrm{C} 12-14$-alkyldimethyl $(4.5 \mathrm{~g} / 100 \mathrm{~g})$, $\mathrm{n}$-oxides (1-<5\%); D6 - didecyldimethylammonium chloride $(5 \mathrm{~g} / 100 \mathrm{~g})$, quaternary ammonium compounds benzyl C12-16 alkyldimethyl, chlorides (4.5g/100g), propan-2-ol (5-<10\%); D7 - propan-1-ol (45g/100g), propan-2-ol (30g/100g); D8 - propan-1-ol (50\%), propan-2-ol (30\%)

strains were not found in raw materials and final products during the study. In turn, Skowron et al. (2020) isolated 127 strains of $L$. monocytogenes from 6,000 surface swabs of poultry, pork and beef (2016-2018).

An important issue significantly affecting determination of the proper sanitary procedures, and thus the reduction of cross-contamination, is the assessment of genetic similarity between strains isolated within a processing plant. Martin et al. [29], analyzing 18 meat plants, detected persistent strains of L. monocytogenes (106 isolates) in the raw material, RTE products and food contact surfaces. In this study, RAPD-PCR confirmed the presence of the same genotype on the floor of the smokehouse at an interval of 2 months. L. monocytogenes can persist in the food production environment even for a few years. This may be due to the permanent recontamination with the pathogen from the external environment or high survival of Listeria strains in the food processing plant. The survival in such an environment is frequently associated with an irregular structure of the surface (microslots, cracks), and the ability of bacteria to form biofilm $[16,28,30,31]$.

An effective disinfection procedure is based on the correct selection of a disinfectant, its concentration and contact time. Testing the antimicrobials action against pathogens begins with planktonic forms of bacteria. In the presented study, the best activity against planktonic bacteria, after 1 and 5 min contact, was shown by disinfectants D1, D2, D5 and D6. The increased time of the exposure resulted in a higher reduction of bacteria in the case of D4 and D7 agents. The high efficacy of sodium hypochlorite, the main component of D1 and D5, applied against both planktonic and biofilm forms of Listeria, was also noted by Cabeça et al. [32]. The positive correlation between antibacterial efficiency and prolonged time of disinfectant action has been confirmed by other researchers $[33,34]$.
In the present study, L. monocytogenes strains were isolated from the environment of a meat processing plant where residues of the production process, such as blood or meat juice, were present. The addition of blood to the growth medium reduced the anti-listerial action of the most disinfectants applied at low concentrations. Wiktorczyk et al. [35] noticed that a $20 \%$ addition of sheep blood significantly increased the number of bacteria from the biofilm. In contrast, Addeen et al. [34] reported that medium supplementation with the blood did not change the bacteria number. In the current study, the addition of albumin reduced the efficacy of sodium hydroxide and sodium hypochlorite (D1, D5) against planktonic forms of bacteria. Skowron et al. (2019) showed that in the case of higher availability of nutrients in the environment where the biofilm was formed, it was more sensitive to disinfection. In turn, Kyoui et al. (2016) showed that biofilm formed in conditions of increased availability of nutrients is characterized by greater resistance to disinfectants. The meat processing environment is rich in blood and meat imprint, and this aspect should be taken into account when selecting a disinfectant.

The biofilm structure makes the eradication of bacteria from such a community much more difficult than their planktonic forms $[16,36,37,38]$. It has been shown (Smith and Hunter, 2008), that bacterial cells in the biofilm structure differ phenotypically from cells in the planktonic form, especially in the degree of resistance to disinfectants. The bacterial resistance to antimicrobials in biofilm might be even 10-1,000 times higher [39]. The biofilm formation affects bacterial resistance to stress factors, including the disinfectants used to limit microbiological contamination of the food processing environment, thereby becoming a serious problem for food safety $[37,40]$. Resistance of biofilm to disinfectants varies depending on its structure, maturity, 
and the surface type on which it is formed $[4,42,43,44]$. Doijad et al. [17] found that L. monocytogenes is able to form biofilm within 24 hours on the majority of materials used in food processing plants, including stainless steel, polyethylene, polyvinyl chloride, glass and ceramics. In turn, Skowron et al. [21] noted the ability to form biofilm by L. monocytogenes on surfaces of rubber, stainless steel, polypropylene and aluminum foil after 24 hours. Poimenidou et al. [45] stated that the type of surface affects the formation of biofilm by L. monocytogenes. They showed that the average number of cells in the biofilm on the surface of polystyrene $\left(5.6 \log \mathrm{CFU} \times \mathrm{cm}^{-2}\right)$ was higher than on stainless steel $\left(4.7 \log \mathrm{CFU} \times \mathrm{cm}^{-2}\right)$ [45]. Thus, biofilm synthesis plays an important role in bacteria transfer from the surface to food products [37]. In the present study, the highest efficacy against biofilm, formed on both stainless steel and polypropylene surface, was observed for agents containing hydrogen peroxide (D3). The reduction of bacteria number was 6.93 and $6.70 \log \mathrm{CFU} \times \mathrm{cm}^{-2}$ after 1-minute application, and 6.93 and $7.21 \log \mathrm{CFU} \times \mathrm{cm}^{-2}$ after 5-minute application, for stainless steel and polypropylene surfaces, respectively. This supports the research of Skowron et al. [46]. Earlier studies by Lineback et al. [47] and Zineb et al. [48] showed the effectiveness of these agents also against Pseudomonas aeruginosa, Staphylococcus aureus, Staphylococcus warneri and Staphylococcus sciuri biofilms. Moreover, Boyce et al. [49] found a lower risk of recontamination of such treated surfaces compared to the use of quaternary ammonium compounds.

In turn, the lowest reduction in the L. monocytogenes number after 1 min exposure was reported for D4 disinfectants (containing nitric (V) and phosphoric acids). Similar results were obtained by Best et al. [50] which showed that phosphoric acid was ineffective against $L$. monocytogenes. The results of this study prove that for the majority of disinfectants the extension of time exposure increased bacteria elimination from the biofilm. Similar tendency observed Bas et al. [42]. In our study the greatest difference in the bacteria number reduction between 1- and 5-minute exposure was observed for the disinfectant D4 containing nitric and phosphoric acids, whereas the time extension did not influence activity of the agent D3. Hence, the extended action of disinfectants may reduce disinfection costs and limit the risk of food recontamination.

An important aspect is also the influence of temperature on the effectiveness of disinfection. The current study was conducted at room temperature. Similar results were obtained by Ren and Frank (1993), who obtained high effectiveness of benzalkonium chloride in combating the biofilm produced by L. monocytogenes at $21^{\circ} \mathrm{C}$. In turn, Skowron et al. (2019) showed that biofilm is susceptible to disinfectants with increasing temperature.

The person in charge of the cleaning and disinfection in the processing plant must take into account the prevalence of biofilm formation by microorganisms, its structure, and differentiated resistance to disinfectants. It is advisable to periodically change the active substance of a given disinfectant and checking its effectiveness.

\section{CONCLUSION}

The research aimed at the possibilities of L. monocytogenes control and elimination in the meat production environment. The appropriate disinfection procedures adjusted to specific production conditions may effectively reduce the risk of listeriosis - one of the most serious food-borne disease. It is proven that the chemical agents commonly recognized as being effective, may not act on the resistant pathogens or the bacteria in biofilm $[16,38,40,44]$. In turn, inefficient disinfection might lead to VBNC [viable but non-culturable] bacteria affecting the reliability of microbiological analyses during monitoring of the sanitary state of the production environment [51].

The study shows that for the majority of disinfectants the extension of time exposure increased bacteria elimination from the biofilm. Since the elimination of the biofilm structure is a problem of special importance for food producers, they should consider the prolongation of disinfectants contact time as an important factor reducing the risk of food recontamination.

Despite the fact that the presence of animal blood and meat proteins in the meat production environment appears to be natural, only a few studies have analysed the effect of blood or albumin on L. monocytogenes resistance to biocides used for disinfection purposes. The most novel and important findings in the study were that the addition of blood to the growth medium resulted in the reduction of the anti-listerial action of most of the disinfectants applied at low concentrations. The presence of albumin reduced the efficacy of sodium hydroxide and sodium hypochlorite against planktonic forms of L. monocytogenes.

The authors believe that the results obtained will enable meat producers to reduce significantly the risk of Listeria contamination in meat processing plants. Nonetheless, further studies on the effective eradication of this pathogen from food plants is of great importance.

\section{REFERENCES}

1. Saraiva C, García Díez J, Fontes M, et al. Modeling the Behavior of Listeria monocytogenes in Meat. 2018; http://dx.doi.org/10.5772/ intechopen.79967

2. Shamloo E, Moghadam ZA, Nazari K, et al. Long Term Survival of Listeria monocytogenes in Stress Conditions: High $\mathrm{pH}$ and Salt Concentrations. J Res Med Dent Sci. 2018; 6, 96-100.

3. Gandhi M, Chikindas LM. Listeria: A foodborne pathogen that knows how to survive. Int J Food Microbiol. 2007; 113, 1-15.

4. European Union One Health. (2018). Zoonoses Report. (2019). https:// www.efsa.europa.eu/en/efsajournal/pub/5926 Accessed 15 February 2020.

5. Health Department of Republic of South Africa. (2018). Listeriosis outbreak situation report - 27/04/2018. WHO Country Emergency Preparedness and Readiness Technical Meeting Listeriosis Outbreak in collaboration with MoH and Partners. Johannesburg 19-21 April 2018.

6. ECDC. (2018). A long term (2015-2018) multi-country outbreak of L. monocytogenes ST6 resulted in 47 confirmed listeriosis cases and 10 fatalities.

7. CDC. (2019). Outbreak of Listeria Infections Linked to Deli Ham (Final Update).

8. Gómez D, Iguácel LP, Rota MC, et al. Occurrence of Listeria monocytogenes in Ready-to-Eat Meat Products and Meat Processing Plants in Spain. Foods, 2015; 14, 271-282. https://doi.org/10.3390/ foods 4030271.

9. Dade-Robertson M, Keren-Paz A, Zhang M, et al. Architects of nature: growing buildings with bacterial biofilms. Microb Biotechnol. 2017; 10, 1157-1163. https://doi.org/10.1111/1751-7915.12833. 
10. Bridier A, Sanchez-Vizuete P, Guilbaud M, et al. Biofilm-associated persistence of food-borne pathogens. Food Microbiol. 2015; 45: 167-178. doi: 10.1016/j.fm.2014.04.015

11. Baranowska M, Chojnowski W, Nowak H. Disinfection in diary plants. Nauki Inżynieryjskie i Technologie. 2014; 4(15): 9-22.

12. Coughlan LM, Cotter PD, Hill C, et al. New weapons to fight old enemies: novel strategies for the (bio)control of bacterial biofilms in the food industry. Front Microbiol. 2016; 7: 1641.

13. El-Azizi M, Farag N, Khardori N. Efficacy of selected biocides in the decontamination of common nosocomial bacterial pathogens in biofilm and planktonic forms. Comp Immunol Microbiol Infect Dis. 2016; 47: 60-71.

14. Van Houdt R, Michiels CW. Biofilm formation and the food industry, a focus on the bacterial outer surface. J Appl Microbiol. 2010; 109(4): 1117-1131. doi: 10.1111/j.1365-2672.2010.04756.x

15. Li J, Feng J, Ma L, et al. Effects of meat juice on biofilm formation of Campylobacter and Salmonella. Int J Food Microbiol. 2017; 253: 20-28. https://doi.org/10.1016/j.ijfoodmicro.2017.04.013

16. Fagerlund A, Møretrø T, Heir E, et al. Cleaning and Disinfection of Biofilms Composed of Listeria monocytogenes and Background Microbiota from Meat Processing Surfaces. Appl Environ Microbiol. 2017; 83(17). doi: 10.1128/AEM.01046-17

17. Doijad SP, Barbuddhe SB, Garg S, et al. Biofilm-Forming Abilities of Listeria monocytogenes Serotypes Isolated from Different Sources. PLoS ONE. 2015; 10(9). https://doi.org/10.1371/journal.pone.0137046

18. PN-ISO 18593: 2004. Microbiology of Food and Animal Feeding Stuffs-Horizontal Methods for Sampling Techniques from Surfaces Using Contact Plates and Swabs (ISO 18593:2004) Polish Committee for Standardization.

19. PN-ISO 11290-1: 2017. Microbiology of the food chain - Horizontal method for the detection and enumeration of Listeria monocytogenes and of Listeria spp. - Part 1: Detection method (ISO 11290-1:2017) Polish Committee for Standardization.

20. Leclercq A, Clermont D, Bizet C, et al. Listeria rocourtiae sp. nov. Int J Syst Evol Microbiol. 2010; 60, 2210-2214. https://doi.org/10.1099/ ijs.0.017376-0

21. Skowron K, Hulisz K, Gryń G, et al. Comparison of selected disinfectants efficiency against Listeria monocytogenes biofilm formed on various surfaces. Int Microbiol. 2018; 21: 23-33.

22. Park S, Jung J, Choi S, et al. Molecular Characterization of Listeria monocytogenes Based on the PFGE and RAPD in Korea. Adv Microbiol 2012; 2: 605-616. doi: 10.4236/aim.2012.24079

23. Ozbey G, Hasan Ertas HB, Filizkok F. Prevalence of Listeria species in camel sausages from retail markers in Aydin province in Turkey and RAPD analysis of Listeria monocytogenes isolates. Irish Vet J. 2006; 59: 342-344.

24. Krzywicka H, Janowska J, Tadeusiak B, et al. Metoda określania stężeń użytkowych preparatów dezynfekcyjnych. Metoda nośnikowa. Warszawa: Wydawnictwo Metodyczne Państwowego Zakładu Higieny; 1993.

25. PN-ISO 1276:2000. Chemiczne środki dezynfekcyjne i antyseptyczne -- Ilościowa zawiesinowa metoda określania działania bakteriobójczego chemicznych środków dezynfekcyjnych i antyseptycznych stosowanych w sektorze żywnościowym, warunkach przemysłowych i domowych oraz zakładach użyteczności publicznej- Metoda badania i wymagania (faza 2, etap 1).

26. The Brussel Times: Five dead in listeria outbreaks in the Netherlands and Germany 2019. https:/www.brusselstimes.com/all-news/belgiumall-news/71673/five-dead-in-listeria-outbreaks-in-the-netherlandsand-germany/. Accessed 15 February 2020.

27. Muhterem-Uyar M, Dalmasso M, Bolocan A, et al. Environmental sampling for Listeria monocytogenes control in food processing facilities reveals three contamination scenarios. Food Control. 2015; 51: 94-107. https://doi.org/10.1016/j.foodcont.2014.10.042

28. Zuber I, Lakicevic B, Pietzka A, et al. Molecular characterization of Listeria monocytogenes isolates from a small-scale meat processor in Montenegro, 2011-2014. Food Microbiol. 2019; 79: 116-122. https:// doi.org/10.1016/j.fm.2018.12.005

29. Skowron K, Wałecka-Zacharska E, Wiktorczyk-Kapischke N, et al. Assessment of the Prevalence and Drug Susceptibility of Listeria monocytogenes Strains Isolated from Various Types of Meat. Foods. 2020; 9: 1293. https://doi.org/10.3390/foods9091293

30. Martin B, Perich A, Gómez D, et al. Diversity and distribution of Listeria monocytogenes in meat processing plants. Food Microbiol. 2014; 44: 119-27. https://doi.org/10.1016/j.fm.2014.05.014

31. Buchanan RL, Gorris LGM, Hayman MM, et al. A review of Listeria monocytogenes: An update on outbreaks, virulence, dose-response, ecology, and risk assessments. Food Control 2017; 75: 1-13. https:// doi.org/10.1016/j.foodcont.2016.12.016

32. Skowron K, Wiktorczyk N, Grudlewska K, et al. Drug-susceptibility, biofilm-forming ability and biofilm survival on stainless steel of Listeria spp. strains isolated from cheese. Int J Food Microbiol. 2019; 2: 75-82. htps://doi.org/10.1016/j.ijfoodmicro.2019.02.021

33. Cabeça T, Pizzolitto A, Pizzolitto E. Activity of disinfectants against foodborne pathogens in suspension and adhered to stainless steel surfaces. Braz J Microbiol. 2012; 43: 1112-1119. http://dx.doi. org/10.1590/S1517-83822012000300038

34. Aarnisalo K, Salo S, Miettinen H, Suihko ML, et al. Bactericidal efficiencies of commercial disinfectants against Listeria monocytogenes on surfaces. J Food Saf. 2000; 20: 237-250. http://doi: 10.1111/j.17454565.2000.tb00302.x

35. Addeen A, Benjakul S, Maqsood S, et al. Chicken blood promotes growth of Listeria monocytogenes, Salmonella Typhimurium, Campylobacter jejuni and Pseudomonas aeruginosa in minced chicken during refrigerated storage. Int Food Res J. 2015; 22: 2619-2728.

36. Wiktorczyk N, Grudlewska K, Skowron K, et al. The effect of blood on the ability of biofilm formation by Listeria monocytogenes strains. Med Res J. 2018; 3, 28-31. doi: 10.5603/MRJ.2018.0005

37. Skowron K, Wałecka-Zacharska E, Grudlewska K, et al. Disinfectant Susceptibility of Biofilm Formed by Listeria monocytogenes under Selected Environmental Conditions. Microorganisms. 2019; 7: 280. doi: 10.3390/microorganisms7090280

38. Kyoui D, Hirokawa E, Takahashi H, et al. Effect of glucose on Listeria monocytogenes biofilm formation, and assessment of the biofilm's sanitation tolerance. Biofouling. 2016; 32: 815-826. doi: 10.1080/08927014.2016.1198953

39. Yun HS, Kim Y, Oh S, et al. Susceptibility of Listeria monocytogenes biofilms and planktonic cultures to hydrogen peroxide in food processing environments. Biosci Biotechnol Biochem. 2012; 76: 20082013. https://doi.org/10.1271/bbb.120238

40. Pang X, Yuk HG. Effects of the colonization sequence of Listeria monocytogenes and Pseudomonas fluorescens on survival of biofilm cells under food-related stresses and transfer to salmon. Food Microbiol. 2019; 82: 142-150. https://doi.org/10.1016/j.fm.2019.02.002

41. Rodríguez-Melcón C, Riesco-Peláez F, García-Fernández C, et al. Susceptibility of Listeria monocytogenes planktonic cultures and biofilms to sodium hypochlorite and benzalkonium chloride. Food Microbiol. 2019; 82: 533-540. g/10.1016/j.fm.2019.03.020

42. Smith K, Hunter IS. Efficacy of common hospital biocides with biofilms of multi-drug resistant clinical isolates. J. Med. Microbiol. 2008; 57: 966-973. doi: 10.1099/jmm.0.47668-0

43. Mah TF, O’Toole GA. Mechanisms of biofilm resistance to antimicrobial agents. Trends Microbiol. 2001; 9: 34-39. https://doi.org/10.1016/S0966842X(00)01913-2

44. Hou J, Wang C, Rozenbaum RT, Gusnaniar N, et al. Bacterial Density and Biofilm Structure Determined by Optical Coherence Tomography. Sci Rep. 2019; 9: 9794. https://doi.org/10.1038/s41598-019-46196-7

45. Barbosa J, Grzybowski V, Cuppini M, et al. Listeria monocytogenes adhesion to food processing surfaces (boning knives) and the removal efficacy of different sanitizers. Ital J Food Sci. 2016; 28: 733-743. https:// doi.org/10.14674/1120-1770/ijfs.v109

46. Bas S, Kramer M, Stopar D. Biofilm Surface Density Determines Biocide Effectiveness. Front Microbiol. 2017; 8: 2443. doi: 10.3389/ fmicb.2017.02443

47. Reis-Teixeira FBD, Alves VF, Martinis ECP. Growth, viability and architecture of biofilms of Listeria monocytogenes formed on abiotic surfaces. Braz J Microbiol. 2017; 48: 587-591. https://doi.org/10.1016/j. bjm.2017.01.004

48. Russo P, Hadjilouka A, Beneduce L, et al. Effect of different conditions on Listeria monocytogenes biofilm formation and removal. Czech J Food Sci. 2018; 36: 208-214. https://doi.org/10.17221/199/2017-CJFS

49. Poimenidou SV, Chrysadaakou M, Tzakoniati A, et al. Variability of Listeria monocytogenes strains in biofilm formation on stainless steel and polystyrene materials and resistance to peracetic acid and quaternary ammonium compounds. Int J Food Microbiol. 2017; 237: 164-171.

50. Skowron K, Grudlewska K, Krawczyk A, et al. The effectiveness of radiant catalytic ionization in inactivation of Listeria monocytogenes planktonic and biofilm cells from food and food contact surfaces as a method of food preservation. J App Microbiol. 2018; 124: 1493-1505. https://doi.org/10.1111/jam.1371

51. Lineback CB, Nkemngong CA, Wu ST, et al. Hydrogen peroxide and sodium hypochlorite disinfectants are more effective against Staphylococcus aureus and Pseudomonas aeruginosa biofilms than 
quaternary ammonium compounds. Antimicrob Resist Infect Control, 2018; 17: 154. https://doi.org/10.1186/s13756-018-0447-5

52. Zineb G, Mliji M, Youssef G, et al. Anti-Adhesion and Anti-Biofilm Effectiveness of Disinfectants Used In Hemodialysis against both Staphylococcus Warneri and Staphylococcus Sciuri Biofilms. Int J Eng Res App. 2014; 4: 86-96.

53. Boyce MJ, Guercia KA, Sullivan L, et al. Prospective cluster controlled crossover trial to compare the impact of an improved hydrogen peroxide disinfectant and a quaternary ammonium based disinfectant on surface contamination and health care outcomes. Am J Infect Control. 2017; 45: 1006-1010. https://doi.org/10.1016/j.ajic.2017.03.010
54. Best M, Kennedy ME, Coates F. Efficacy of a Variety of Disinfectants against Listeria spp. Appl Environ Microbiol. 1990; 56(2): 377-380.

55. Overney A, Jacques-André-Coquin J, Ng P, et al. Impact of environmental factors on the culturability and viability of Listeria monocytogenes under conditions encountered in food processing plants. Int J Food Microbiol. 2017; 244: 74-81. https://doi.org/10.1016/j. ijfoodmicro.2016.12.012

56. Ren TJ, Frank JF. Susceptibility of Starved Planktonic and Biofilm Listeria monocytogenes to Quaternary Ammonium Sanitizer as Determined by Direct Viable and Agar Plate Counts. J Food Prot. 1993; 56: 573-576. doi: 10.4315/0362-028X-56.7.573 